\title{
Directions Of Hydrogen Power Development In Tatarstan Republic
}

\author{
Antonina Filimonova ${ }^{1}$, Andrey Chichirov ${ }^{1,{ }^{*}}$, Natalya Chichirova $^{1}$, Artem $_{\text {Filimonov }}{ }^{1}$, and Alexandr Pechenkin ${ }^{1}$ \\ ${ }^{1}$ Kazan State Power Engineering University, Russia
}

\begin{abstract}
Green hydrogen is a promising solution for a decarbonized energy system, and in 2020 the use of hydrogen has increased dramatically around the world. In order to draw attention to the problem of hydrogen energy in Russia and the Republic of Tatarstan, the article analyzes the development paths and main opportunities for the production, transportation, and use of hydrogen at the enterprises of Tatarstan, and calculates the economic efficiency of the "green" hydrogen production by electrolysis at TPPs with CCGTs in Tatarstan. METHODS. Research methods are based on the analysis of literature data and mathematical calculations. RESULTS. Tatarstan, as one of the leading economically developed regions of Russia, could take part in the "green" hydrogen production, the electrochemical equipment design for its production, the development of technologies for the fuel cells use, research and training of highly qualified specialists in the field of hydrogen energy. According to the calculations, the production of the most environmentally friendly hydrogen at TPPs with CCGT in Tatarstan will currently cost an average of 2 euros per kilogram, which is significantly lower than the existing market value. CONCLUSION. Tatarstan can become a competitive region for the "green" hydrogen production and distribution. The main areas of activity should be the pure hydrogen production, the industrial production of freight transport on fuel cells, the production of megawatt-class electrolysers, the utilization of hydrogen-containing petroleum gases at TPPs in gas turbines or in combined cycle power plants with fuel cells.
\end{abstract}

\section{Introduction}

Hydrogen is considered the main building block in the foundation of the future sustainable energy supply systems [1-4]. Therefore, the priority direction in the field of hydrogen economy (politics) for our country and its leading regions, such as Tatarstan, is the high-purity hydrogen production and its transportation to other countries, as well as the development of the hydrogen energy production in our country [5].

\section{Literature review}

Tatarstan is a leading economically developed region. The republic is located in the center of a large industrial region of the Russian Federation, at the intersection of the most important highways connecting the east and west, north and south of the country. The Republic of Tatarstan has significant economic potential and promising human capital. Competitive advantages of Tatarstan are its favorable geographical position, rich natural resources, highly qualified labor resources, a powerful industrial and scientific complex, and a developed transport infrastructure.

In the structure of the gross regional product of Tatarstan, the share of industry is $48.1 \%$, agriculture $5.6 \%$, construction sector $-8.1 \%$, transportation and storage $-4.8 \%$. The industrial profile of the Tatarstan
Republic is determined by the oil and gas chemical complex, large machine-building enterprises producing competitive products, as well as developed electrical and radio equipment. Tatarstan is a region of highly intensive agricultural production. Occupying $2.2 \%$ of Russia's farmland, the republic produces $4.2 \%$ of its gross agricultural output.

In the Republic of Tatarstan, great attention is paid to the introduction of new promising technologies. The sites for the creation and development of innovative projects based on technology and IT parks, zones with preferential taxation, various development centers, including increasing energy efficiency, efficient operation. Tatarstan has not only a huge research and production potential to create technologies for the production, use and distribution of hydrogen fuel to other regions and countries, but also, in addition to the scientific base, a production structure ready to introduce new technologies and bring it to a qualitatively significant level of economic functioning.

The production and consumption of hydrogen in Tatarstan is mainly (over 90\%) associated with industrial use. The main industrial consumers are the chemical industry $(63 \%)$, oil refineries $(30 \%)$, metalworking $(6 \%)$ and energy $(1 \%)$.

The largest manufacturer of heavy trucks, one of the twenty leading world manufacturers, the Tatarstan enterprise «KAMAZ» is developing a project to create

* Corresponding author: aachichirova@mail.ru 
an 18-ton hydrogen car (fig.1) and a hydrogen fuel cell bus. It is planned to install fuel cells of domestic production, developed by InEnergy together with the Institute of Problems of Chemical Physics in Chernogolovka. In connection with such a project, a demand has already arisen in Tatarstan for its own production of high purity hydrogen for fuel cells.

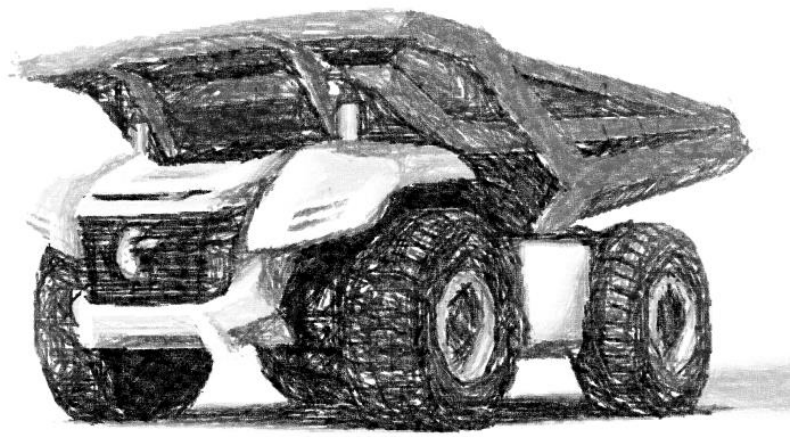

Fig. 1. Fuel cell truck project.

Green hydrogen is seen as a key decarbonization vector for the wider energy sector, as it can be used for zero-carbon transport, heating, heavy industry, long-term energy storage and as a base for carbon neutral synthetic fuels. But "green" $\mathrm{H}_{2}$ is $50-300 \%$ more expensive than "gray hydrogen" produced from natural gas. This is partly due to the fact that electrolysers have not yet been industrialized and are still mainly manually produced in relatively small quantities. This sector is rapidly developing, and the scaling effect is expected to lead to lower cell costs and green hydrogen more economically available by about $50 \%$ this decade. One of the directions for the development of Tatarstan's hydrogen economy could be the industrial production of megawatt-class electrolysers, especially since machine building, electrical equipment production is developed in Tatarstan and there is a strong scientific and technological base [6].

While humankind wants green hydrogen, reaching this milestone may require a transition phase of blue, brown and gray hydrogen in the short term to accelerate hydrogen demand and supply. Moreover, oil and gas companies are extremely interested in this. These enterprises cannot produce "green" hydrogen, but can participate in the production of "gray" and "blue" hydrogen [7]. In this regard, Tatarstan has the opportunity to offer all types of hydrogen for a smooth transition from "gray" to "green".

As the global economy strives to become carbonneutral, competitive renewable hydrogen has become a key component of the energy mix.

The economics of a power-to-gas (P2G) operation based on the hydrogen production by electrolysis can be significantly improved if it is included in the grid ancillary services [8]. Ancillary services are part of the electric power system and are used to balance temporary variations between production and consumption of electricity and thus ensure the safe and smooth operation of the electric power system [9]. It should be borne in mind that the operation of sustainable energy sources (hydro, photovoltaic and wind) is highly dependent on the weather and, therefore, cannot meet real energy needs. This problem is becoming more serious with the introduction of many new sustainable energy sources. It is estimated that for every $100 \mathrm{MW}$ of newly installed sustainable energy sources, 4-10 MW of ancillary services are needed to maintain a balanced grid. Typically, systems included in ancillary services provide additional electricity when there is a shortage and provide additional consumption or energy storage when there is excess electricity in the system.

According to the Ministry of Energy of Russia, according to the state program for supporting renewable energy sources, $3.4 \mathrm{GW}$ of wind power plants, $2.2 \mathrm{GW}$ of solar power plants and $210 \mathrm{MW}$ of mini-hydroelectric power plants should be commissioned in Russia by 2024. Tatarstan could work in tandem with renewable energy facilities actively developing in neighboring regions. For example, a wind farm in the Ulyanovsk region of the Fortum company, SPP facilities in Bashkortostan and others.

According to the Minister of Industry of the Republic of Tatarstan Albert Karimov, the construction of a wind farm in Tatarstan will begin in 2021 with commissioning in 2024 .

Distributed energy can become another vector for the development of hydrogen energy in Tatarstan. This is especially important, given the high territorial distribution of consumers of the republic's oil-producing complex and agricultural facilities. The idea is to create small, distributed solid oxide fuel cell power plants that can be used in cities, industry, trade and commerce, data centers and electric vehicle charging infrastructure. Taking into account the ability of high-temperature fuel cells to operate on "dirty" hydrogen, in this case it is possible to use the hydrogen-containing gas mixture formed during oil refining.

\section{Materials and methods}

Materials and methods include a review of the literature and available statistical data in order to analyze the current situation and predict the potential for Tatarstan to obtain, store, use and distribute hydrogen fuel.

In order to conduct an economic assessment of the investment attractiveness of introducing a system of using electricity of its own production at a CCGT to generate "green" hydrogen, mathematical calculations of the economic feasibility of producing "green" hydrogen at TPPs with a CCGT in Tatarstan in the current market conditions were carried out.

\section{Results}

It is known that currently selling prices for hydrogen can range from 10 to $60 € / \mathrm{kg}$ [4], where $60 € / \mathrm{kg}$ is the price of hydrogen with a particularly high degree of 
purity used for semiconductors and special applications. With this in mind, a more reliable approach to predict the hydrogen price is to analyze its production costs.

For the transport sector, the projected market value of hydrogen by 2025 is according to FCH JU (Fuel Cells and Hydrogen Joint Undertaking) public-private partnership of industry and the European Commission on fuel cells and hydrogen, taking into account different levels of hydrogen production technologies implementation will decrease from 10-20 euros to 4.5-7 per kilogram [ 4].

In the Russian wholesale market, electricity prices have fluctuated on average around 17-20 euros / MWh over the past decade, where the production price is about $30 \%$ lower. At the same time, the cost of electricity generation at TPPs with CCGT is approximately 1.5 times lower than at traditional TPPs. The use of new combined cycle technologies with natural gas as a source fuel is a generally recognized global technology that does not have an economically viable alternative [10]. The Republic of Tatarstan has a wide range of CCGT units with $\mathrm{E}, \mathrm{F}$ and $\mathrm{H}$ class gas turbines, i.e. virtually the entire global range of technologies up to the most advanced class $\mathrm{H}$ with efficiency up to $65 \%$. Kazan CHP-1 and Kazan CHP-2 installed (in 2018 and 2014, respectively) 2 CCGT units with F-class gas turbines such as GE PG6111FA (MS6001F / FA) with a capacity of 77 MW each. Since 2017, Kazan CHPP-3 has been operating the only H-class GTU GE 9HA.01 in Russia with a capacity of $405.6 \mathrm{MW}[11,12]$.

PJSC "Nizhnekamskneftekhim" will commission a 500 MW CCGT unit from 2021 for the company's own needs with Siemens E-class gas turbines using blow-offs from petrochemical plants as fuel, including petroleum gas refined products from the existing ethylene production facility. At the Zainsk SDPP, in 2025, it is planned to commission a CCGT unit with a capacity of 858.3 MW with a GE 9HA.02 gas turbine unit.

To increase operating profitability, an assessment was made of the feasibility of introducing a P2G system [13-17] at TPPs with CCGTs for the production of green hydrogen in order to increase operational efficiency and subsequently achieve financial benefits.

The primary stage in converting electricity to hydrogen is the construction of a system for converting energy to gas at a TPP with a CCGT. The three main building blocks that make up the $\mathrm{P} 2 \mathrm{G}$ unit are the electrolyser, the hydrogen / oxygen buffer tank system together with water fraction separation components and final storage prior to hydrogen distribution to end users or further processes [18].

The technical characteristics of one of the typical commercially available $\mathrm{P} 2 \mathrm{G}$ systems are used to calculate the costs of producing green hydrogen for CHPPs.

Technical parameters:

- Rated power - $1 \mathrm{MW}$;

- Hydrogen productivity - $300 \mathrm{~nm}^{3} /$ hour;

- Hydrogen capacity regulation - 15-100\%;

- Specific power consumption - $4.4 \mathrm{kWh} / \mathrm{nm}^{3}$;

- Hydrogen pressure at the outlet - 30-200 kgf/ $\mathrm{cm}^{2}$
The capital cost for the installation and operation of the P2G system will be $€ 2,200,000$ and the operating costs $€ 110,000$ per year. The total annual electricity consumption in the P2G system is $9460.8 \mathrm{MWh}$.

The cost of hydrogen production at TPPs with CCGT units consists of two parts - capital and operating costs for equipment and maintenance of the $\mathrm{P} 2 \mathrm{G}$ system, the cost of electricity for the operation of the $\mathrm{P} 2 \mathrm{G}$ system and hydrogen production.

According to the calculations the production price of hydrogen will be 2.16 euro $/ \mathrm{kg}$.

\section{Findings}

The expected rise in greenhouse gas emissions and a heavy reliance on fossil energy sources are compelling reasons for moving to new alternatives and an incentive for industrial actors to invest in various new green energy technologies. Hydrogen is a promising energy carrier, but current production and operating methods do not match the long-term environmental and energy goals. In Tatarstan, as one of the most economically developed regions of the Russian Federation, fuel cell trucks and buses are already being designed and there is an industrial production of hydrogen, both pure and contaminated with by-products. But production requires significant expansion, with an emphasis on "green" as the most demanded hydrogen. In addition, hydrogen is produced locally, i.e. it is necessary to develop and implement systems for delivering it to other regions and countries. The price of producing "green" hydrogen at TPPs with CCGT in Tatarstan using an electrolysis system is lower than the market price for hydrogen predicted by various studies for the next decade. Thus, Tatarstan may well become a competitive region for the production and distribution of "green" hydrogen.

\section{References}

1. A. Filimonova, A. Chichirov, N. Chichirova, A. Filimonov, V. Kulichikhin, Reliability and safety of energy, 2 (2019)

2. Information and analytical edition of the Infrastructure Center EnergyNet NTI, Energy Transition (hydrogen), 39 (2020)

3. Information and analytical edition of the Infrastructure Center EnergyNet NTI, Energy Transition (hydrogen), 40 (2020)

4. D. Fraile, J. Lanoix, P. Maio, A. Rangel, A. Torres, Overview of the Market Segmentation for Hydrogen Across Potential Customer Groups [Electronic resource], Based on Key Application Areas. European Commission (2015) Available at: http://www.certifhy.eu/images/D1_2_Overvie w_of_the_market_segmentation_Final_22_June_1 ow-res.pdf

5. I. Dincer, Int. J. Hydrogen Energy, 37 (2012) [19]. 
6. IRENA, Green Hydrogen Cost Reduction: Scaling up Electrolysers to Meet the $1.5^{\circ} \mathrm{C}$ Climate Goal, International Renewable Energy Agency, Abu Dhabi (2020)

7. International Energy Agency, The Future of Hydrogen, Seizing Today's Opportunities, International Energy Agency: Paris, France (2019)

8. A. Mazza, E. Bompard, G. Chicco, Renew. Sustain, Energy Rev, 92 (2018)

9. A. Kaushal, D. Van Hertem, D. Hertem, Energies, 12 (2019)

10. D. Jovan, G. Dolanc, Energies, 13 (2020) DOI: 10.3390/en13246599

11. A. Filimonova, N. Chichirova, A. Chichirov, A. Batalova, A. Filimonov, Trunsactions of Academenergo, 3 (2020)

12. A. Filimonov, A. Filimonova, N. Chichirova, A. Valeev, Bulletin of KGEU 2 (2019)

13. A. Lewandowska-Bernat, U. Desideri, Appl. Energy, 228 (2018)

14. S. Schiebahn, T. Grube, M. Robinius, V. Tietze, B. Kumar, D. Stolten, Int. J. Hydrogen Energy, 40 (2015)

15. C. Van Leeuwen, M. Mulder, Appl. Energy, 232 (2018)

16. D. Fischer, F. Kaufmann, O. Selinger-Lutz, C. Voglstätter, Int. J. Hydrogen Energy, 43 (2018)

17. Z. Chen, Y. Zhang, T. Ji, Z. Cai, L. Li, Z. Xu, J. Mod. Power Syst, Clean Energy, 6 (2018)

18. Overview of the hydrogen market and equipment for its production in Russia [Electronic resource], INFOMINE Research Group, 3rd edition Moscow (April 2018) Available at: http://www.infomine.ru/research/14/248

19. N.E.L. Hydrogen, Containerized Atmospheric Alkaline Electrolyser [Electronic resource] Available at: https://nelhydrogen.com/product/atmospheric alkaline-electrolyser-a-series/ 